\title{
Critical Thinking Skills: Developing a Course to Guide our World toward Ethical Decision-Making
}

Current Research in Psychology and Behavioral Science (CRPBS)

\author{
Walsh-Soucheray $\mathbf{K}^{\star}$ \\ Doctor of Education Theology, Marriage and Family Therapy, Licensed Marriage and Family Therapist, USA \\ Abstract \\ Many people would have us believe that teaching critical thinking skills is not possible, but that these are skills \\ we are born with, or not. This is simply not true. Understanding that making good decisions is something that must be \\ taught, because young people in our current culture are engulfed in worldwide societies that purport little ethical or moral \\ guidance. Due to the dearth of good role modeling for character, the important skill of critical thinking must be addressed \\ in our churches, our schools, and our homes. We cannot leave this important skill to social media and peers and have the \\ expectation that our young people will understand how to become good, moral citizens of our world.
}

Received date : 10 February, 2022

Published date: 28 February, 2022

\section{*Corresponding author}

Kate Walsh-Soucheray, Doctor of Education, Theology, Marriage and Family Therapy, Licensed Marriage and Family Therapist, Emeritus, USA

\section{Key Words}

Ethical; Critical thinking; Character;

Values; Virtue

Distributed under: Creative Commons CC-BY 4.0
Introduction

Critical Thinking Skills are proficiencies that we often take for granted and assume will naturally develop with age and maturity (Brookfield, 1987). However, this is not necessarily the case, which often leaves adolescents and adults making poor choices and wondering why they did what they did at the moment of decision. In fact, adults who would be considered senior citizens have been heard to comment, "It sounds like you're asking us to think. Do you know how much easier it was to just follow the rules?"

\section{Discussion}

Moon [1] explains "it could be argued that the general picture of the good critical thinker is of a person who is autonomous. The whole point of thinking critically is to find an appropriate response or a decision in a judgment" (p. 55). Moon [1] explains that it is not simply the processes of critical thinking in which we engage that determines the quality of our decision-making, but the enhanced level in our competence of thinking. Therefore, simply following the rules correctly does not verify that the individual is able to think critically, at an enhanced level of competency. According to Day [2,3], critical thinking is "a rational approach to decision making that emphasizes careful analysis and evaluation" (p. 205). The process of learning to think critically "begins with an understanding of the subject to be evaluated, moves to identifying the issues, information, and assumptions around the problem, and then concludes with evaluating alternatives and reaching a conclusion" (p. 205). Johnson [3] explains that "our values serve as a moral compass to guide us on our journey. Values provide a frame of reference, helping us to set priorities and to distinguish right from wrong" (p. 102). Johnson [3] continues as he purports "moral processes consist of moral projects and moral work. Moral projects are designed to improve ethical behavior during a limited amount of time and require 'moral leaders"' (p. 91). The development of our moral compass, through engaging in moral projects and moral work, helps to develop our character [3]. According to Lickona [4], "character shapes the destiny of an individual person. It shapes the destiny of a whole society" (p. 4). Lickona [4] explains that the development of character helps individuals, as well as societies, become virtuous, which is the foundation of a happy and fulfilling life. Lickona [4] provides ten virtues he considers as essential, which include wisdom, justice, fortitude, selfcontrol, love, positive attitude, hard work, integrity, gratitude, and humility [4].

Additionally, Wheatley (2006) contends that our ability to become the best of ourselves occurs through self-reference which sets us apart from other species, however, we don't use our gifts to be more aware or thoughtful. We're driven in the opposite direction. Things move too fast for us to reflect, demanding tasks give us no time to think, and we barely notice the lack of meaning until forced to stand still by illness, tragedy, or job loss (p. 147). Therefore, due to the "speed, complexity, and diversity of our world" [5], thinking freely and competently, as opposed to simply following the rules, is something that must be actively taught, rather than the acceptance of rule-following as a forgery for critical thinking. When we discuss rules, we must ask whose rules will we follow, what will be required of us to follow these rules, what will happen if we break the rules, and how will we determine the standards of the rules, based on culture, ethnicity, gender, identities of all sorts, as well as a myriad of other unnamed determinates. Without any doubt, we are living in a confusing time, which explains why we might prefer following preordained rules over our own autonomous thinking [6]. In many ways, this confusing time has been confounded by the overabundance of information we have at our fingertips, as well as the speed and immediacy at which this information reaches us, often leaving us with little intellectual space to think critically (Wheatley 2006). Someone might wonder if we have foregone the critical step of learning to think and to process information as it comes to us, via our cell phones and other electronic devices. Rather than learning to think critically, it seems we have begun to take whatever information is delivered, no longer asking important questions, such as, Is it true? Is it accurate? Is it well-sourced? And if we choose to pass this information on to others, we must ask if it will contribute to an enhanced sense of humanity, because our decisions always have a moral quality to them [4]. When we distance ourselves from this moral aspect of decision-making, we also disconnect, to some degree, from our common humanity (Wheatley 2006)

Richard Sparks [7], author of Contemporary Christian Morality, delineates the process of good, moral decision-making. First, we must ask ourselves these questions: What act am I thinking of engaging in? Where, when, and how will I take part in this act? What are the likely consequences of this act and what alternatives are available to me? Finally, we must ask ourselves why we are thinking of making this decision. Such a process slows down our thinking process and engages us in a procedure to think systematically through the decision we face from a perspective that is slightly removed from the situation. It is from 
this vantage point that a logical, ethical, moral decision can be made that is less likely to create regret or shame for the decision-maker at a later point in his or her life [7].

\section{Conclusion}

It is through careful, thoughtful decision-making that we develop our character and the quality and depth of our moral being. From the decisions we make, the nex decisions become available to us, because decisions take on a trajectory. Critical thinking skills are important for the development of a moral, character-driven adulthood, which provides an individual with the ability to think freely and logically, as well as empathically, which are qualities of well-formed, free-thinking adults $[4,8]$. Consider developing a critical thinking course for your students, your employees, and the families that reside in your city, county, state, or province. Accept that teaching critical thinking skills requires patience and trust in the process of teaching these skills, which is not only important, but fundamental, to the development of a free, logical, and empathic citizenship and work force. Teaching critical thinking skills will provide moral guidance to your children, adolescents, and adults for generations, as it provides the basis of a free and cohesive world for all $[4,9]$.

\section{References}

1. Moon J (2008) Critical thinking: An exploration of theory and practice. $1^{\text {st }}$ edn.
Routledge publishers, UK, pp. 1-248.

2. Day LA (2006) Ethics in media communications: Cases and controversies. $5^{\text {th }}$ edn., Cengage Learning, US, pp. 1-480.

3. Johnson CE (2015) Meeting the ethical challenges of leadership: Casting light and shadow. $7^{\text {th }}$ edn., Sage Publishers, US, pp. 1-536.

4. Lickona T (2004) Character matters: How to help our children develop good judgment, Integrity, and other essential virtues. Atria Publishers, USA, pp. $1-336$.

5. Lester G (2015) Class notes from "Personality Disorders".

6. Lickona T (1991) Educating for character: How our schools can teach respect and responsibility. Bantam publishers, USA, pp. 1-496.

7. Sparks RC (1996) Contemporary christian morality: Real questions/candid responses. 1st edn., Crossroads Publishers, USA, pp. 1-184.

8. Vitz PC, Nordling WJ, Titus CS (2020) A Catholic Christian meta-model of the person: Integration with psychology \& mental health practice. Divine Mercy University Press, US, pp. 1-736.

9. Groome T (1998) Educating for life: A spiritual vision for every teacher and parent. Crossroad Publishing, US, pp. 1-472. 